Esta publicación cientifica en formato digital es continuidad de la revista impresa ISSN-Versión Impresa 0798-1406 / ISSN-Versión on line 2542-3185Depósito legal pp
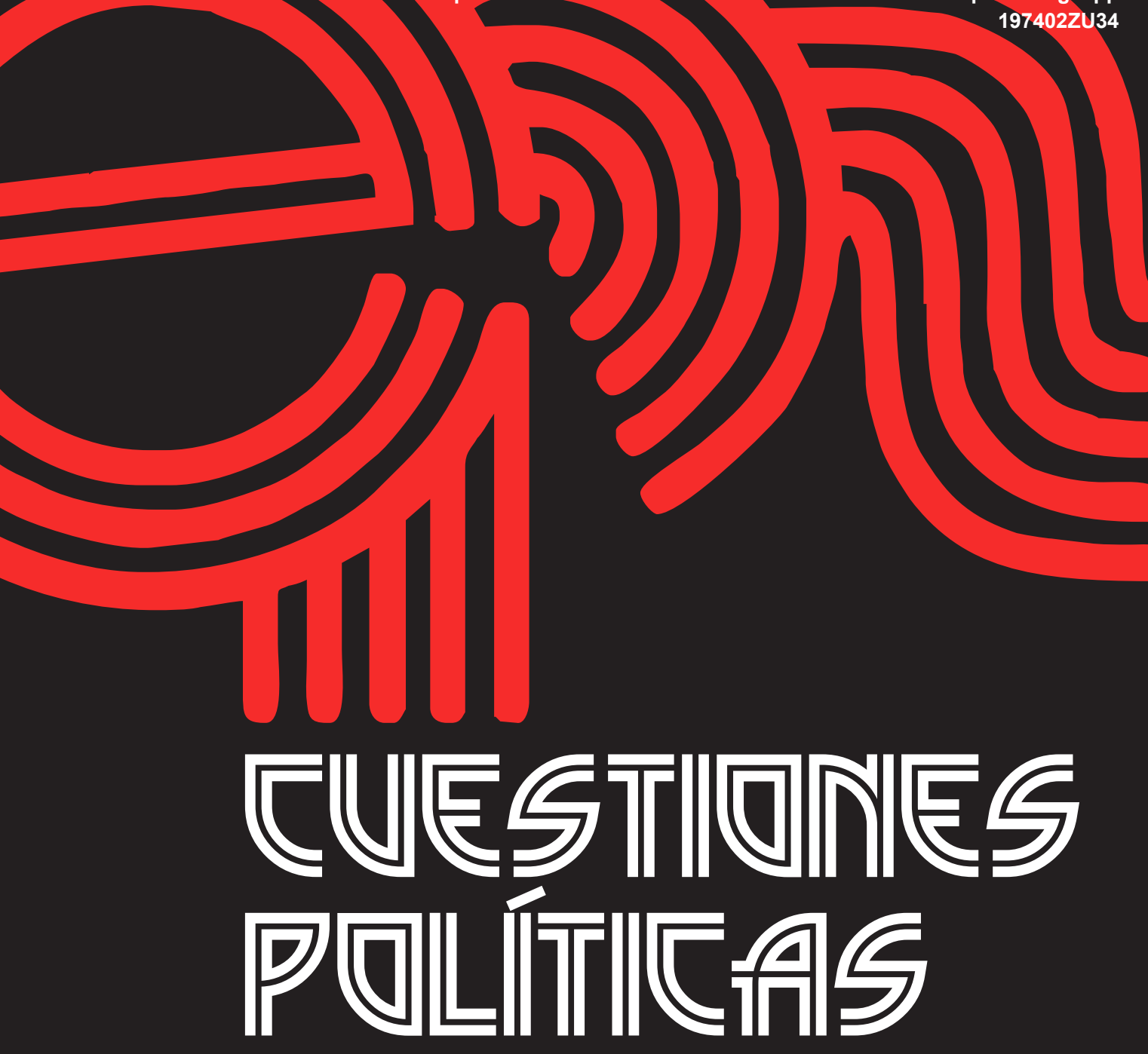

Instituto de Estudios Políticos y Derecho Público "Dr. Humberto J. La Roche" de la Facultad de Ciencias Jurídicas y Políticas de la Universidad del Zulia Maracaibo, Venezuela
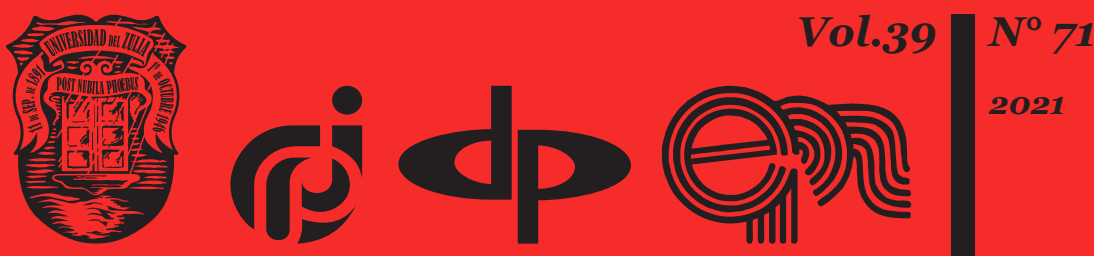


\title{
Criminal protection of children's life and health: international experience
}

\author{
DOI: https://doi.org/10.46398/cuestpol.3971.18
}

\author{
Viktoria Babanina * \\ Vita Ivashchenko ** \\ Oleg Grudzur *** \\ Yurikov Oleksandr ****
}

\begin{abstract}
Through a documentary methodology, the article examines the characteristics of the criminal protection of the life and health of children in Ukraine and some other countries. The problem of determining the time of the beginning of the protection of a child's life and health, is analyzed in the light of the European experience. It is noted that in Ukraine it is necessary to recognize the right to live of the child at any stage of fetal development, to ensure the criminal protection of the child before birth. This approach is enshrined in several international legal acts, as well as confirmed by legal guarantees in the legal systems of many countries around the world. In addition, the article analyzes criminal law measures to guarantee the rights and interests of the child under modern Ukrainian law. The list of socially dangerous acts against minors is a result, so reinforced criminal liability is provided for considering the interests of minors. It has been concluded that in all post-Soviet countries the components of crimes against a person's health, considering the legislator's reaction to causing harm to the health of children during their commission, are clearly divided into three separate
\end{abstract} groups.

Keyword: criminal protection of children; life and health; children and minors; criminal responsibility; corpus delicti.

Professor of Criminal Law Department of the National Academy of Internal Affairs, PhD in Law, Associate Professor, Kyiv, Ukraine. ORCID ID: https://orcid.org/oooo-0003-4173-488X

** Professor of Criminology and Criminal Executive Law Department of the National Academy of Internal Affairs, PhD in Law, Associate Professor, Kyiv, Ukraine. ORCID ID: https://orcid.org/oooo-ooo16076-3657

*** Associate Professor of Criminal Law Department of the National Academy of Internal Affairs, PhD in Law, Kyiv, Ukraine. ORCID ID: https://orcid.org/oooo-0002-1691-3328

**** Teacher of the cycle of general and criminal law disciplines Kyiv Center for Primary Vocational Training «Police Academy» Educational and Scientific Institute № 1 of the National Academy of Internal Affairs, PhD in Law, Kyiv, Ukraine. ORCID ID: https://orcid.org/oooo-0002-6900-6887 


\section{Protección penal de la vida y la salud de los niños: experiencia internacional}

\section{Resumen}

Mediante una metodología documental el artículo examina las características de la protección penal de la vida y la salud de los niños en Ucrania y algunos otros países. El problema de determinar el momento del inicio de la protección de la vida y la salud de un niño se analiza teniendo en cuenta la experiencia europea. Se observa que en Ucrania es necesario reconocer el derecho a la vida del niño en cualquier etapa del desarrollo fetal, para garantizar la protección penal del niño antes de su nacimiento. Este enfoque está consagrado en una serie de actos jurídicos internacionales, así como confirmado por garantías legales en los sistemas legales de muchos países del mundo. Además, el artículo analiza las medidas de derecho penal para garantizar los derechos e intereses del niño bajo la ley ucraniana moderna. Es resultado la lista de los actos socialmente peligrosos contra los menores, para que es prevista la responsabilidad penal reforzada teniendo en cuenta los intereses de los menores. Se ha concluido que en todos los países postsoviéticos los componentes de los delitos contra la salud de una persona, teniendo en cuenta la reacción del legislador al hecho de causar daño a la salud de los niños durante su comisión, están claramente divididos en tres grupos separados.

Palabras clave: protección penal del niño; vida y salud; infancia y menores; responsabilidad penal; corpus delicti.

\section{Introduction}

There is no doubt about the importance of ensuring the necessary protection of human rights to life and health. The special importance of human life and health as the most important intangible values has led to the consolidation of human rights to life and standard of living necessary to maintain health and care for illness or disability at the international level, in particular in the Universal Declaration of Human Rights (Art. 25) and the International Covenant on Economic, Social and Cultural Rights (Article 11). These provisions are concretized at the constitutional level of each country, in particular, Art. 3 of the Constitution of Ukraine proclaims human life and health as the highest social value. Ensuring the right to life and health is also detailed at the sectoral level, in particular, at the level of criminal law, which provides for liability for crimes against life and health.

Human life is not only a subjective right, protected by legal norms, but also an independent social, spiritual and biological value. Protecting 
Viktoria Babanina, Vita Ivashchenko, Oleg Grudzur y Yurikov Oleksandr
352 Criminal protection of children's life and health: international experience

everyone's life is a top priority for criminal law. Many lawyers have devoted their work to the issue of criminal law protection of life, but their work does not cover all the problems of criminal law regarding comprehensive protection of life.

Crimes that affect the life and health of a person are the most socially dangerous acts. Today, special attention needs to be paid to the protection of the lives and health of children, who, due to their age, are the most vulnerable category of the population.

Problems of securing children, protecting their rights and legitimate interests, in particular, from socially dangerous encroachments, must be constantly in the focus of attention of a democratic state. Crimes committed against a child, or related to his coercion, involvement in their commission, are characterized by increased social danger. They can not only cause physical, moral or property damage to the child, but also negatively affect its further development, causing unpredictable consequences. Criminal protection of children's rights is an important part of their protection system. In the process of further European integration and development of the rule of law in Ukraine, it is important to clarify the vectors of the domestic legislator in the field of criminal law protection of children's rights and compare Ukrainian legal provisions on children's rights protection with legislation of other countries.

\section{The problem of determining when to start protecting the life and health of a child}

There are many different points of view on the question of the beginning of life in the legal and medical literature. Researchers determine the beginning of human life from a certain stage of physiological childbirth. At the same time, one group of scientists believes that human life begins from the moment when the child is capable of independent existence, completely separated from the mother's body and took the first breath (Naumov, 2005; Lysenko, 2002). However, back in 1923, S. Pozdnyshev wrote that the most convincing proof of the life of the newborn is breathing. However, there may be cases when the child has not yet breathed, but already lived through the bloodstream (Pozdnyshev, 1923).

Some authors suggest that the initial limit of human life should be associated with the appearance of the formed mass of brain cells, which makes the fetus viable (Sharapov, 2005). Proponents of this position have conclude that, from a legal point of view, the beginning of human life is the birth (formation) of the brain, namely: the achievement of the fetus 22 weeks of fetal development (Trubnikov, 2009). 
At the same time, it should be noted that in the modern criminal law literature attempts are made to determine the beginning of life in a different way. Thus, according to Professor V. Glushkov, the life of a human fetus after twenty-eight weeks is an additional object of illegal abortion, so his death because of an illegal operation should be classified as murder (Glushkov, 1987).

Regarding the beginning of life, the position of M. Korzhansky, who notes that the beginning of physiological childbirth is when the development of the fetus is over and it is ripe for independent life outside the mother's body, at that moment a new life appears, which must already be protected by criminal law (Korzhansky, 2001).

At the same time, there is a point of view according to which the moment of the beginning of life is the moment of fertilization (Popov, 2001; Poroshuk, 1998). In jurisprudence, there are strong trends to support this point of view. Thus, some scientists point out that the period of intrauterine human development is an early period of its biological life. Being in the womb in the state of the embryo, it is physically independent, because it is not part of the body of its carrier and is capable of self-development: because the life processes occurring in it, act as an internal impulse of its development.

The mother's body is only an ideal environment for development. With birth begins the second stage of biological existence of man, or rather, the stage of his body in the social environment. This indicates the fallacy of the existing idea that human life begins at birth (Jurek, 2020).

This should be corrected: a person's social life begins from the moment of his birth (Selikhova, 2002).

Some authors believe that the legal relationship to the status of embryos should be based on the recognition of the fact that the embryo is not part of the mother's body, but the beginning of a new life (Besedkina, 2005). It should be emphasized that this position has its own normative consolidation. In the civil legislation of Ukraine in Art. 1222 of the Civil Code of Ukraine, the right to inherit arises from a person who was conceived during the life of the testator and born alive after the opening of the inheritance.

Supporting this approach, Professor A. Kovler emphasizes that "modern law strongly defines another boundary: human life begins with the fertilization of the egg" (Kovler, 2002: 128).

Unfortunately, at the legislative level, the moment of the beginning of life is not clearly established. Only in the Instruction on definition of criteria of the perinatal period, live birth and stillbirth, approved by the order of the Ministry of Health No. 179 from March 29, 2006 (Ministry of Health of Ukraine, 2006), it is specified that live birth is expulsion or 
removal from mother's body a fetus which after expulsion / withdrawal (regardless of the duration of pregnancy, whether the umbilical cord is cut and whether the placenta has detached) breathes or has any other signs of life, such as palpitations, pulsation of the umbilical cord, certain movements of skeletal muscles, although from this definition it is not clear what should be considered the beginning of human life. The Instruction focuses on the criteria that indicate whether a person was born alive.

The solution to the problem of criminal-legal consolidation of the moment of the beginning of protection of life should be sought considering foreign, first of all, European legislative experience.

According to the legislation of most European countries, human life begins at conception, and the child at the prenatal stage of development before birth is the very fact of its existence, including the fact of being in physical (biological) relationship with his mother, has a certain legal status that entitles him to protection.

Traditionally, the prenatal period is divided into three stages: the zygote stage (about two weeks), the embryo stage (from the 2nd to the 8th week) and the fetal stage (from the 9th week before birth).

The terms "zygote", "embryo" and "fetus" are used exclusively to indicate the stages of ontogenetic development of the human individual but cannot be grounds for recognizing the lack of value of the child's life at the prenatal stage of development.

According to the Judgment of the Grand Chamber of the European Court of Justice (Court of Justice of the European Union) in Case No. C-34/10 of 18 October 2011 (Court of Justice of the European Union, 2011) concerning the interpretation of Article 6 (2) (c) of Directive 98 / 44 / EU of the European Parliament and of the Council of 6 July 1998: "On the legal protection of biotechnological inventions", a human ovum from the moment of fertilization must be considered as a "human embryo" (European Parliament and the Council, 1998: 55).

The presence of a person at the initial (prenatal) stage of his life and development does not give legal grounds to treat him (and accordingly - his life) as an object that is not a human individual and has no right to life.

The right of such a child to life by its legal nature follows from the natural human right to life and must be recognized by the state as the highest value. Thus, the state is obliged to recognize the need for legal protection of life and health of a child in the prenatal stage of development and to establish legal guarantees for the right of such a child to life, his right to normal development and criminal protection of his health from conception (Urbaniak and Spaczynski, 2015). 
The legislation of most European Union countries enshrines rules that guarantee the right to life, health, and other rights of a child in prenatal development. A child in the prenatal stage of life should be legally recognized a number of fundamental rights, including the right to life, safety and protection, to receive proper care and nutrition, to receive special criminal protection from all forms of negligence, violence, intentional and unintentional abuse and other actions that may harm its development.

It is obvious that at present the levels and specific measures of legal protection of a person born and legal protection of a person in the prenatal period of development in different states differ significantly, but it does not follow that the obligation of the state to respect and protect human rights in the prenatal period is less important (or that there is no such obligation of the state at all) and that a person in the prenatal period is deprived of any legal protection.

Thus, the legal recognition of a child at any stage of fetal development as a subject of the right to life, the legal recognition of the rights of such a child to life, health care and development, as well as criminal protection before birth is expressed in a number of provisions of international legal acts, and also is confirmed by the legally established guarantees in legal systems of many states.

\section{Criminal-legal measures to ensure the rights and interests of the child under modern Ukrainian legislation.}

According to the modern Criminal Code of Ukraine, issues of criminal liability and punishment of minors are resolved in a separate Section of the General Part "Features of criminal liability and punishment of minors". The existence of a special system of punishment for juveniles is justified by their biological, psychological, and social characteristics, so public authorities must take into account all the peculiarities of the age of minors and their psychological and social characteristics to administer humane and democratic justice to persons of this social group.

Separation of features of criminal responsibility of minors in the independent section means that concerning these persons norms on criminal responsibility are applied considering the special provisions provided in this section. Minors between the ages of fourteen and eighteen, on the one hand, reach a fairly high level of socialization, namely: they have independence, perseverance, ability to control their behavior, etc., and on the other, there is further socialization of the individual: training continues or ends in school or college, experience of interpersonal relations, etc. is accumulated. This age is characterized by excessive categorical judgments, irritability, imbalance, inability to assess the situation taking into account 
all the circumstances. These age features have led to the establishment of a number of exceptions and additions to the liability of minors compared to the general rules of criminal liability (Astemirov, 1970). Assessing the content of the section of the Criminal Code of Ukraine on criminal liability and punishment of minors, it should be borne in mind that this section is an integral part of the General Part of the Criminal Code, it is inextricably linked with other provisions.

This connection is manifested primarily in the fact that all the initial provisions on the tasks and principles of criminal law on the grounds of criminal liability, the effect of criminal law in time, space and circle of persons, the concepts and types of crimes, guilt and its types, complicity, about the circumstances that exclude the criminality of the act and some others also apply to minors who have committed crimes. The General Part of the Criminal Code contains norms on the peculiarities of children's responsibility for committing criminal offenses and does not preclude the extension to the latter of other privileged norms of the General Part of the Code.

The authorities of all countries of the world make a lot of efforts to establish their country in the international arena as an independent, sovereign, democratic and legal state.

An important characteristic that determines the authority of any state in the international arena to some extent is the policy to protect the rights and freedoms of its citizens, especially the youngest. At the same time, modern social conditions in which adolescents are born, grow and are brought up are far from the desired well-being. Socio-economic crisis phenomena in Ukraine, such as unemployment, indifference to the upbringing of young people, impoverishment of the population, directly affect the formation of the younger generation in the country.

It is important that it is the modern social conditions in which minors grow up and are brought up in some cases that alienate minors from official institutions of socialization, such as the family and the school. According to the State Statistics Service of Ukraine, the country has a low birth rate, which does not provide even a simple reproduction of generations. However, despite the low birth rate, alcohol consumption is becoming increasingly important among young people, the phenomenon of the first drug attempts among adolescents aged eleven to twelve has become widespread, and drug addiction and sexually transmitted diseases are spreading. Social neglect of minors in the conditions of pluralism of views, the absence of clear moral guidelines contributes to the emergence and spread of negative phenomena among minors, which generates crime (Kretsul, 2016).

The world community has repeatedly called for issues related to the protection of the rights and legitimate interests of children. In Art. 3 of 
the Convention on the Rights of the Child emphasizes that in all actions concerning children, regardless of which public or private enterprise they use, priority must be given to the best interests of the child (United Nations, 1989).

Similar protection of the rights of the child is enshrined in the Minimum Standard Rules for Juvenile Justice - the Beijing Rules (United Nations General Assembly, 1985) and in the Universal Declaration of Human Rights (United Nations, 1948). On September 30, 1990, the United Nations General Assembly adopted the Universal Declaration on the Survival, Protection and Development of Children, which called for all children to be able to identify themselves as individuals and to realize their potential in a safe and favorable environment, among seven or caregivers who ensure their well-being (United Nations General Assembly, 1990). Based on this requirement of the Universal Declaration of Human Rights and recognizing that a minor at any age is a person who has all the rights of a member of society, he must also be recognized as having the right to the protection of the law.

Criminal law in Ukraine, protecting the interests of minors, their physical and mental development, provides for increased responsibility for the following socially dangerous acts against them:

- $\quad$ Premeditated murder of the mother of her newborn child (Article 117 of the Criminal Code); infection of a minor with immunodeficiency virus (Part 3 of Article 130 of the Criminal Code).

- Infection of a minor with a sexually transmitted disease (Part 2 of Article 133 of the Criminal Code).

- Leaving the mother in danger of a newborn child (Part 2 of Article 135 of the Criminal Code).

- Improper performance of responsibilities for the protection of life and health of children (Article 137 of the Criminal Code).

- Illegal experiments on humans (Part 2 of Article 142 of the Criminal Code).

- Unlawful deprivation of liberty or kidnapping (Part 2 of Article 146 of the Criminal Code).

- Hostage-taking (Part 2 of Article 147 of the Criminal Code).

- Human trafficking (Part 2 of Article 149 of the Criminal Code).

- Exploitation of children (Article 150 of the Criminal Code).

- The use of a minor child for begging (Article 150-1 of the Criminal Code). 
Viktoria Babanina, Vita Ivashchenko, Oleg Grudzur y Yurikov Oleksandr
358 Criminal protection of children's life and health: international experience

- Rape (parts 2, 3, 4 of Article 152 of the Criminal Code).

- Forcible gratification of sexual passion in an unnatural way (parts 2, 3 of Article 153 of the Criminal Code).

- Sexual intercourse with a person who has not reached sexual maturity (Article 155 of the Criminal Code).

- Depravity of minors (Article 156 of the Criminal Code).

Also, there should be mentioned:

- Import, production, sale, and distribution of pornographic items (Part 2 of Article 301 of the Criminal Code).

- Creation or maintenance of cities of debauchery and pimping (Part 3 of Article 302 of the Criminal Code).

- Pimping or involving a person in prostitution (parts 3, 4 of Article 303 of the Criminal Code).

- Involvement of a minor in criminal activity (Article 304 of the Criminal Code).

- Illegal production, manufacture, purchase, storage, transportation of narcotic drugs, psychotropic substances, or their analogues (parts 2, 3 of Article 307 of the Criminal Code).

- Illegal introduction into the body of narcotic drugs, psychotropic substances, or their analogues (Part 3 of Article 314 of the Criminal Code).

- Predisposition to the use of narcotic drugs, psychotropic substances or their analogues (Part 2 of Article 315 of the Criminal Code).

- Organization or maintenance of places for illegal use, production or manufacture of narcotic drugs, psychotropic substances, or their analogues (Part 2 of Article 317 of the Criminal Code).

In practice, the right of children and adolescents to protection of their physical and spiritual development exists formally and this right arises there and when it comes to bringing them to justice (Shedlosky, 2008). As can be seen from the above list of norms of the Criminal Code, today the right to life and health of a child is guaranteed by criminal law on a common basis with adults. The Criminal Code contains virtually no rules specifically regulating liability for encroachment on the lives and health of adolescents. Their age is taken into account only as an aggravating circumstance in determining the culprit. It is obvious that murder, intentional infliction of grievous bodily harm on a minor is an increased social danger. As an example: in paragraph 2 of Part 2 of Art. 115 of the Criminal Code of Ukraine provides for increased liability for premeditated murder of a person under the age of 14, i.e., a minor child. 
In particular, D. Kalmykov, conducting research on criminal liability for the exploitation of children, determines that the Ukrainian legislator has supported the global trend regarding the rights of the child, enshrining in Part 2 of Art. 52 of the Constitution of Ukraine that any violence against a child and its exploitation are prosecuted by law, and the provisions of parts 3, 5 of Art. 43 of the Constitution of Ukraine categorically forbade the use of forced labor of children and labor of children in work dangerous to their health (Kalmykov, 2011).

At the same time, despite the different legal decisions on the protection of children's rights, the consideration of violations of children's rights provides for the need to take more decisive measures. Thus, D. Kalmykov proposes to explain Article 150 of the Criminal Code of Ukraine "Exploitation of Children" as the use of forced labor of a child who has not reached the age of sixteen with qualifying characteristics for a minor, or for two or more children, etc. (Kalmykov, 2011).

I. Dolyanovska, considering criminal liability for exploitation of children, proves the need for provision in Art. 150 of the Criminal Code of Ukraine is not responsible for the exploitation of children, but for the economic exploitation of children, which is consistent with the provisions of the UN Convention on the Rights of the Child (Dolyanovska, 2008). I. Dolyanovska believes that the forms of sexual exploitation of a child are all cases of satisfaction of sexual needs of persons, in which the culprits receive profit from such activities of the victim. The author argues that criminal liability for sexual exploitation of children should be provided in Art. 149 of the Criminal Code of Ukraine. In this context, the concept of "sexual exploitation" was developed, which proposed to supplement paragraph 1 of the Note to Art. 149 of the Criminal Code of Ukraine: the use of children's activities to meet the sexual needs of third parties in order to make a profit by the perpetrators (Dolyanovska, 2008).

The current situation in Ukraine regarding the application of criminal law to children (minors) is in a difficult position. Despite the fact that the current Criminal Code of Ukraine still contains norms of a privileged, more human nature for children, there are still a large number of gaps. The most important thing is that there are norms in the current international law that could fill the gaps in the legislation of Ukraine, although the positive trend should include the fact that the basic international legal acts have been ratified by Ukraine today. 
Viktoria Babanina, Vita Ivashchenko, Oleg Grudzur y Yurikov Oleksandr
360 Criminal protection of children's life and health: international experience

\section{Comparative analysis of criminal protection of life and health of a child under the laws of Ukraine and other countries}

First, it should be mentioned that the corpus delicti of crimes against a person's health, taking into account the reaction of the legislator to the fact of causing harm to children's health during their commission, is very clearly divided into three separate groups. The first such group consists of infection with human immunodeficiency virus or other incurable infectious disease and sexually transmitted diseases, the composition of which provides for their commission against minors as particularly qualifying features under the legislation of Ukraine (Part 3 of Article 130 and Part 2 of Article 133 of the Criminal Code), the Republic of Belarus (Part 3 of Article 157 and Part 3 of Article 158 of the Criminal Code), Georgia (Article 131 and Article 132 of the Criminal Code), the Republic of Moldova (Part 3 of Article 212 and Part 2 of Article 212 of the Criminal Code), the Russian Federation (Part 3 of Article 122 and Part 2 of Article 121 of the Criminal Code).

The second group, the so-called opposite to the first, are acts during which the infliction of bodily harm to children does not affect their qualifications under the criminal law of Ukraine or the criminal law of these post-Soviet states (intentional grievous bodily harm caused in the state intentional infliction of grievous bodily harm in the event of exceeding the limits of selfdefense or in excess of the measures necessary to apprehend the offender; negligent grievous or moderate bodily harm).

Finally, the third group of crimes against the health of a person, which under the law of other post-Soviet (except Ukraine) states provide for / recognize their commission of children as a sign of a crime that affects its qualification, includes intentional grievous bodily harm; intentional moderate bodily injury; intentional minor bodily injury; beatings; torture.

Along with the above-mentioned general positive provision of criminal legislation of some post-Soviet of child health care by normative fixing of crimes referred to the third group, we will pay attention to the existence of so-called normative-legal differences.

For example, the criminal codes of the Republic of Bulgaria and the Republic of Lithuania contain as qualified corpus delicti crimes against children in articles that provide for liability for: intentional grievous bodily harm (Article 131, Article 135); intentional moderate bodily injury (Article 131, Article 138); intentional minor bodily injury (Article 131, Article 140); beatings and muggings (Article 187, Article 140). According to the legislation of the Republic of Moldova, the following are recognized as qualified crimes: intentional grievous bodily harm (Article 151); intentional moderate bodily injuries (Article 152), their killing as well as the use of juvenile torture (Article 166-1). 
Intentional infliction of the same severe or moderate bodily injuries on minors, as well as the use of torture against them are attributed to the relevant components of crimes, which affects their qualification and the legislation of the Republic of Kazakhstan (Article 106, Article 107, Article 110). In the criminal codes of Georgia and the Russian Federation such qualifying features of corpus delicti as their commission against children are provided in the articles establishing bodily injury (Article 117, Article 111), intentional moderate bodily injury (Article 118, Article 112); torture (Article 126, Article 117). Only the torture of children is recognized as a sign of a crime that affects its qualification in the legislation of the Republic of Azerbaijan (Article 133) and the Republic of Belarus (Article 154).

In general, according to the criminal legislation of foreign countries, encroachment on the health of children as a qualifying feature of the crime is often recognized in the case of torture (Article 133 of the Criminal Code of Azerbaijan, Article 154 of the Criminal Code of Belarus, Article 126 of the Criminal Code of Georgia, Article 140 of the Criminal Code of the Republic of Lithuania, Article 166-1 of the Criminal Code of the Republic of Moldova, Article 117 of the Criminal Code of the Russian Federation), but not so often in case of intentional infliction of grievous and moderate bodily injury (Article 117, Article 118 of the Criminal Code of Georgia, Article 106, Article 107 of the Criminal Code of the Republic of Kazakhstan, Article 135, Article 138 of the Criminal Code of the Republic of Lithuania, Article 152 of the Criminal Code of the Republic of Moldova, Article 111, Article 112 of the Criminal Code of the Russian Federation) and others.

The criminal legislation of the post-Soviet countries is characterized by certain differences in determining the age of children victims of the crimes under investigation.

In most of the criminal codes, juveniles (codes of the Republic of Azerbaijan, the Republic of Belarus, Georgia etc.) are recognized as such victims. According to the criminal legislation of the Russian Federation, the victims of intentional severe and moderate bodily injuries are minors (Article 111, Article 112), and of beatings and torture - minors (Article 117).

It is also worth noting the establishment in the legislation of individual states of criminal liability of parents for specific encroachments on the health of their children. Thus, according to the Criminal Code of the Republic of Lithuania, parents may be liable for causing serious harm to the health of their child (Article 135), as well as damage to the health of minor gravity (Article 135). 
Viktoria Babanina, Vita Ivashchenko, Oleg Grudzur y Yurikov Oleksandr
362 Criminal protection of children's life and health: international experience

\section{Conclusions}

The current situation in Ukraine regarding the application of criminal law to children (minors) is in a difficult position. Even though the current Criminal Code of Ukraine still contains norms of a privileged nature for children, there are still a large number of gaps. The most important thing is that there are norms in the current international law that could fill the gaps in the legislation of Ukraine, although the positive trend should include the fact that the basic international regulations have been ratified by Ukraine today.

First of all, the legal recognition of a child at any stage of fetal development as a subject of the right to life, the legal recognition of the rights of such a child to life, health care and development, as well as criminal protection before birth is expressed in a number of provisions of international legal acts, and also is confirmed by the legally established guarantees in legal systems of many states.

The need to further improve the criminal law protection of children's health in Ukraine is obvious, especially against the background of resolving this issue in criminal law at least in the post-Soviet states. At the same time, we also believe that, given the legal status of children in Ukraine after reaching the age of sixteen, unlawful infliction of bodily harm on a person under the age of sixteen should be considered a sign of a crime against the health of a person who affects his qualifications.

Accordingly, in Art. 67 of the Criminal Code of Ukraine should provide that the aggravating circumstance is the commission of a crime against a person under the age of sixteen.

At the same time, encroachment on the rights, freedoms and interests of a person under the age of sixteen, committed by a close relative or family member, a person charged with the care of the victim or caring for him, should be recognized as an aggravating circumstance, and harm to the health of a person under the age of sixteen by a subject from among the above as a sign of a crime against health, which affects his qualifications.

The general directions of further improvement of the Ukrainian criminal legislation in the field of protection of children are: allocation of the separate section in the Special part of the Criminal Code devoted to crimes in the sphere of a family, guardianship, care and normal development of children; revision of the norms of the Criminal Code for the uniformity of use and the same ratio of the terms "child" and "minor"; improvement and unification of the lists of special subjects of crimes from among parents and persons who replace them (in Articles 150-1, 155, 156, 166, 304, 323) taking into account the provisions of family and civil law; further strengthening the responsibility for certain crimes that may be committed against children. 


\section{Bibliographic References}

ASTEMIROV, Zinoviy. 1970. Criminal liability and punishment of minors. Juridicheskaya literatura. Moscow, Russia.

BESEDKINA, Natalia. 2005. Constitutional and legal protection of the rights of an unborn child in the Russian Federation. Abstract of PhD thesis. Moscow Humanitarian University. Moscow, Russia.

DOLYANOVSKA, Iryna. 2008. "Criminal liability for exploitation of children (Analysis of the crime)". Abstract of $\mathrm{PhD}$ Thesis. National University of Internal Affairs. Kyiv, Ukraine.

EUROPEAN PARLIAMENT AND COUNCIL. 1998. Directive No. 98/44/EC of the European Parliament and of the Council of 6 July 1998 on the legal protection of biotechnological inventions. Available online. In: http:// eur-lex.europa.eu/legal-content/FR/TXT/HTML/?uri=CELEX:31998L 0044\&from=EN. Consultation date: 02/01/2021.

GLUSHKOV, Vitaliy. 1987. Accountability for crimes in the field of health care. Vishcha shkola. Kiev, Ukraine.

JUREK, Tomasz. 2020. "Fetus exposure to HIV infection by mother during pregnancy - legal aspects" In: HIV \& Aids Review. Vol. 19, No. 3, pp. 147152.

JUSTICEOF THE EUROPEAN UNION. 2011. Judgment of the Court of Justice (Grand Chamber). Available online. In: http://curia.europa.eu/juris/ document/document.jsf?text=\&docid=111402\&pageIndex=0\&doclan $\mathrm{g}=\mathrm{FR} \&$ mode $=$ lst $\&$ dir $=\&$ occ $=$ first $\&$ part $=1 \& \mathrm{cid}=416805$. Consultation date: $02 / 01 / 2021$.

KALMYKOV, Dmytro. 2011. "Criminal liability for exploitation of children". Abstract of PhD Thesis. Academy of Advocacy of Ukraine. Kyiv, Ukraine.

KORZHANSKY, Myhailo. 2001. Criminal Law. Legislation of Ukraine. Special Part. Course of lectures. Attica. Kyiv, Ukraine.

KOVLER, Alexandr. 2002. Anthropology of law. Norma Infra-M. Moscow, Russia.

KRETSUL, Vitaliy. 2016. Legal protection of minors and some features of their criminal liability. Legal influence on illegal behavior: current aspects. Ilion. Mykolaiv, Ukraine.

LYSENKO, Vitaliy. 2002. "Problems of determining the initial moment of protection of human life in criminal law" In: Russian investigator. Vol. 2, pp. 38-42. 
Viktoria Babanina, Vita Ivashchenko, Oleg Grudzur y Yurikov Oleksandr
Criminal protection of children's life and health: international experience

MINISTRY OF HEALTH OF UKRAINE. 2006. Instruction on definition of criteria of the perinatal period, live birth and stillbirth, the order of registration of live births and stillbirths: Statement of the Ministry of health of April 12, № 427/12301. Available online. In: https://zakon.rada. gov.ua/laws/show/z0427-06\#Text. Consultation date: 02/01/2021.

NAUMOV, Anatoliy. 2005. The practice of applying the Criminal Code of the Russian Federation: comments on judicial practice and doctrinal interpretation. Walters Kluver. Moscow, Russia.

POPOV, Anatoliy. 2001. Crimes against the person under extenuating circumstances. Legal Center Press. St. Petersburg, Russia.

POROSHUK, Svitlana. 1998. "The human right to life as an object of legal regulation: the current state, problems in Ukraine" In: Bulletin of the Luhansk Institute of Internal Affairs of the Ministry of Internal Affairs of Ukraine. Vol. 2, pp. 3-18.

POZDNYSHEV, Serhii. 1923. Essay on the basic principles of the science of criminal law. Yuridicheskaya literature. Moscow, Russia.

SELIKHOVA, Olga. 2002. Constitutional and legal problems of the exercise of the right of individuals to freedom and personal inviolability. Abstract of $\mathrm{PhD}$ thesis. Ural State Law University. Yekaterinburg, Russia.

SHARAPOV, Roman. 2005. "The beginning of criminal law protection of human life" In: Criminal law. Vol. 1, pp. 70-81.

SHEDLOSKY, Eric. 2008. "Protecting children from the harmful behavior of adults" In: Journal of Criminal Law \& Criminology. Vol. 98, No. 1, pp. 299-327.

TRUBNIKOV, Viktor. 2009. The concept of criminal law protection. Juridical Kharkiv. Kharkiv, Ukraine.

UNITED NATIONS GENERAL ASSEMBLY. 1985. United Nations Standard Minimum Rules for the Administration of Juvenile Justice ( «The Beijing Rules») Adopted by General Assembly resolution 40/33 of 29 November 1985. Available online. In: https://www.ohchr.org/documents/ professionalinterest/beijingrules.pdf. Consultation date: 02/01/2021.

UNITED NATIONS GENERAL ASSEMBLY. 1990.World Declaration on the Survival, Protection and Development of Children. Available online. In: http://www.un-documents.net/wsc-dec.htm. Consultation date: 02/01/2021. 
UNITED NATIONS human rights. 1989. Convention on the Rights of the Child Adopted and opened for signature, ratification and accession by General Assembly resolution 44/25 of 20 November 1989. Available online. In: https://www.ohchr.org/en/professionalinterest/pages/crc.aspx. Consultation date: 02/01/2021.

UNITED NATIONS. 1948. Universal Declaration of Human Rights. Available online. In: https://www.un.org/en/about-us/universal-declaration-ofhuman-rights. Consultation date: 02/01/2021.

URBANIAK, Moniak; SPACZYNSKI, Robert. 2015. "Selected legal aspects of the protection of the unborn child in the light of the draft amendment to the Polish Penal Code" In: Ginekologia polska. Vol. 86, No.10, pp. 787790. 
Vol. 39 N $^{\circ} 71$

Esta revista fue editada en formato digital y publicada en diciembre de 2021, por el Fondo Editorial Serbiluz, Universidad del Zulia. Maracaibo-Venezuela 